\title{
Transatlantica
}

Revue d'études américaines. American Studies Journal

$1 \mid 2012$

Le roman policier, littérature transatlantique / Maisons

Hantées

\section{Sébastien Chauvin, Les Agences de la précarité. Journaliers à Chicago, Paris, Seuil (collection Liber), 2010}

James Cohen

\section{OpenEdition}

\section{Journals}

Édition électronique

URL : https://journals.openedition.org/transatlantica/5701

DOI : 10.4000/transatlantica. 5701

ISSN : 1765-2766

Éditeur

Association française d'Etudes Américaines (AFEA)

Référence électronique

James Cohen, « Sébastien Chauvin, Les Agences de la précarité. Journaliers à Chicago, Paris, Seuil

(collection Liber), 2010 », Transatlantica [En ligne], 1 | 2012, mis en ligne le 21 juin 2012, consulté le 01

février 2023. URL : http://journals.openedition.org/transatlantica/5701 ; DOI : https://doi.org/10.4000/ transatlantica. 5701

Ce document a été généré automatiquement le 1 février 2023

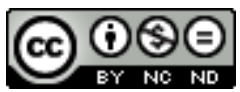

Creative Commons - Attribution - Pas d'Utilisation Commerciale - Pas de Modification 4.0 International - CC BY-NC-ND 4.0

https://creativecommons.org/licenses/by-nc-nd/4.0/ 


\title{
Sébastien Chauvin, Les Agences de la précarité. Journaliers à Chicago, Paris, Seuil (collection Liber), 2010
}

\author{
James Cohen
}

1 The title and subtitle of this work accurately reflect its bold dual ambition to be both a study in the sociology of labor in contemporary capitalism and an ethnographic account of workers' lived experience in a given historical moment and place. In the first of these guises, its purpose is to shed light on the contemporary logics of exploitation of labor power by examining closely, at ground level, the mechanisms of this exploitation as they affect the most precarious sectors of the working class. The chosen terrain of the study is the world of temporary employment agencies in Chicago, specialized in supplying manpower to private employers in light industry. The workers who seek employment via this route, having little choice in the matter, are indeed among the most socially vulnerable in U.S. society: undocumented immigrant workers, nearly all from Mexico and Central America, and chronically unemployed AfricanAmerican men in Chicago and handicapped by a criminal record. This terrain is explored not just for its own sake but also on the hypothesis that it has broader systemic significance, as the embodiment of deep contemporary tendencies in the capitalist control over labor power.

2 At the same time, Sébastien Chauvin is an ethnographer who cultivates the art of communicating in writing a sense of how flesh-and-blood social subjects experience their condition and deal with everyday situations. This mode of comprehension requires an ability to capture minute, sometimes barely visible details of social interaction which nonetheless hold the key to understanding what is at stake in these situations. At this level the author is not discussing abstract or generic workers embodying systemic logics, but real people from given types of social backgrounds. It is indeed at this level that observers gain the clearest understanding of workers' social status, not just as workers but as natives or immigrants, speakers of English or Spanish, ethnically/racially marked subjects (black, white or Latino), men or women. 
3 As an ethnographer, Chauvin is attentive at all times to issues of position and perspective, starting with his own. As a young sociologist hailing from France, he managed to establish a place for himself as a worker in Chicago temporary labor agencies for over two years. While keenly aware of the limits of his outsider status, he made the most of it by recording his experiences in fine narrative detail and giving voice, through numerous interviews, to temporary workers and agency personnel.

4 The body of the work is divided into six densely-packed chapters. Chapter 1 ("Citoyenneté précaire et précarité économique. Noirs et sans-papiers sur le marché du travail aux États-Unis") discusses the general question of precarious laborin relation to civic fragility. Indeed, the temporary laborers whose world the author frequented belong to two highly restrictive regimes of "citizenship"; the majority are Latino immigrants, i.e. not "citizens" in the ordinary sense of "nationals", and further "disqualified" by the fact that most are undocumented, while the minority is made up of individuals who are indeed citizens in the formal, juridical sense but are doubly marked as black males and as ex-convicts-a status which prevents them from finding other types of employment (and even, as the study shows, handicaps their "employability" in the temporary market).

5 Next is a chapter ("L'embauche sans qualité") on the hiring process, analyzed in all its particulars as a process designed to confirm and reinforce, in ritualized fashion, the job candidates' "unqualified" and subordinate status. Sociological discussion revolving around the analysis of social rituals and drawing on Goffman, Garfinkel and Bourdieu among others, provides the main theoretical substance of this chapter, but the dense descriptions of the hiring process itself make for bracing reading. Chauvin sheds light here on the racialized mechanisms of hiring selection and on the use of various types of legal subterfuge used by agencies and "final employers" (the plants or factories) to disguise workers' civic status, thinly but pragmatically, and to minimize labor costs by disguising even the most permanent labor assignments as temporary (hence the paradoxical figure of the permatemp).

Chapter 3, entitled "Tester, réformer et punir. Fonctions et usages du temps dans l'intérim industriel étatsunien," centers on the ways in which time operates as a major constraint on temporary laborers and further reinforces their precarious and subordinate status: waiting lines before the agency even opens at 5 a.m.; long waiting times, which may stretch into weeks, before job assignments are given; significant waiting times for transport to and from assigned workplaces; and, of course, waiting lines for the paycheck distributed by the agency. These constraints, suggests Chauvin, are tests conceived first to verify job candidates' reliability and then to condition them to the discipline of keeping themselves available for temporary labor without showing outward signs of exasperation or humiliation.

7 Chauvin draws from these observations a partial conclusion-to be explored in greater depth further on-which is that precariousness ${ }^{2}$ in its early $21^{\text {st }}$-century guise is anything but a perfect example of labor flexibility, if by that term one means "universal fluidity", implying an equal degree of freedom for employers and employees to dissociate themselves from one another. On the contrary, he writes, in contemporary precariousness employers aim "to establish a minimal level of flexibility while avoiding - at least for workers at the lower end of the wage-earning spectrum and confined to secondary labor markets-having to pay a price in terms of reciprocal freedom for 
workers" (198). The efforts required to keep labor power available as a commodity can be analysed as so many "mechanisms of retention".

The dispatcher-both as embodiment of an assigned role in the temporary labor hiring process and as a concrete social subject of given social background and genderoccupies center stage in chapter 4 ("La sociologie politique du dispatcheur"). The dispatcher is the member of the agency staff who is in closest contact with job candidates because his or her function is to assign them to jobs ("get them on a ticket" in the prevailing lingo). The dispatcher's role is not just one of "economic intermediary" between the agency and the workers but also "cultural intermediary between two worlds", in particular where recent Latin American immigrants are concerned, because to manage such workers dispatchers must be speakers of Spanish. In the job assignment decisions made each day by the dispatcher, the principle of "first come, first served" is frequently respected in the breach, as Chauvin shows, because of employer preferences for certain categories of workers (by gender or ethnicity) but also because of the dispatcher's freedom to decide, outside of any rules of procedure, who will go to work at a given place on a given day. Workers are placed in a position of having to cultivate the favor of dispatchers in order to be considered for a more regular "ticket" and become "more equal than others in the face of uncertainty" (206). In this type of situation they enter into a clientelistic situation in which "the distribution of tickets [job assignments] is regulated by a relationship of gift and counter-gift". The more "casual" temporary workers may play on competition among various agencies, but only at the cost of higher levels of uncertainty vis-à-vis any given agency.

Chapter 5 (“'Selling labor'. Du syndicat entrepreneur à l'agence de travail journalier") examines hidden and not-so-hidden affinities between the functions and the modus operandi of temporary hiring agencies on the one hand, and certain types of labor unions on the other, especially those in the "business union" category. In earlier eras, such unions did not hide the fact that they were "selling labor," that is, controlling the recruitment process, sometimes in purely illicit mafia fashion. In this chapter Chauvin ably rehearses the entire history of the U.S. labor movement from the late $19^{\text {th }}$ century to the present, examining in each era the role of unions in the day labor hiring process, up to the moment when they began losing ground to private day labor agencies. Lobbying efforts in favor of such agencies began to pay off in the 1960s when they were recognized as having the same legal status as other corporations and became less subject to inspections of their books and methods. This summary barely begins to do justice to Chauvin's close reading of history, but narrative is not the only object here. Chauvin also makes a strong theoretical claim: contrary to interpretations of contemporary labor history in which the market and worker organizations are opposed terms, it appears in his analysis that day labor agencies represent a densely organized "market intermediary", that is, a necessary instance of administration and retention allowing labor markets to operate to employers' full advantage.

10 In the final chapter ("Journaliers à l'usine," chapter 6), Chauvin displaces the site of observation from the hiring agency to the "final employer", that is, the factories where nearly all the laborers from Chicago temporary hiring agencies are assigned to work for shorter or longer periods. This change in setting and angle of vision allows the author to examine a wide variety of situations, including those in which temporary workers are clearly subordinate to the rest of the workforce and those in which temps make up nearly all the workers in a company. Within the latter scenario, Chauvin takes a strong 
interest in situations where some workers are able to stabilize their situation and become "permatemps," as opposed to "casual temps," thereby proving that the segmentation between temporary and regular laborers is not a complete segregation, but rather a situation of "overlapping segmentation" (segmentation imbriquée, 321). There are even instances where permatemps find themselves in positions of authority over regular workers and enjoy something outwardly resembling a normal working "career"-which of course does not prevent them from being continually handicapped by their civic status. Permatemps inevitably run into a "cardboard ceiling," as Chauvin puts it, by analogy to the "glass ceiling" of gender discrimination. The processes and stratagems by which some workers gain the favor permatemp status are examined with particular attention.

11 Chauvin strives in his 10 pages of conclusion to draw theoretical ("nomothetic") conclusions from all the phenomena observed. Two closely linked questions are explored: 1) the economic function of day labor agencies in the U.S. and 2) the question of how day labor can be constructed as an "ideal-type of precariousness" capable of shedding light on tendencies visible elsewhere, in "less advanced regimes of precariousness". Such agencies "appear [...] as the 'ideal' organizational instrument [...] for obtaining from precarious laborers, in what could be seen as a post-Fordist 'noncompromise,' the double advantage of their 'contingency' and their subordination" (330), thanks, once again, to the "civic precariousness" or ethnically/racially subordinated groups, which represents a "prior disqualification" that is ratified through a degraded hiring process.

Whatever else it might be, temporary labor does not conform to a common expectation that precariousness means increased "mobility": "the past decades of neoliberal fragilization of wage-earners in the labor market have not, on the average, translated into shorter periods of employment" (333). From the perspective of the workers, "the relevant opposition is not between 'stability' and 'mobility', but rather between 'selfmobility' and constrained mobility." Precarious labor does not necessarily mean intermittent employment; insofar as predictions are possible on the basis of observed reality, the tendency is not toward "universal intermittence" but rather toward a "reassertion of control over mobility via uncertainty" (335). This is not to deny that temporary laborers experience intermittence, but simply to suggest that it is not only a constraint since it can also be "a form of resistance against precariousness [...] via the exit route" (336).

Another major conclusion concerns the ties between precarious labor and state control. Chauvin suggests that precarious labor cannot be fully understood as a social relation unless it is seen in the context of state efforts to make such labor the only option available to certain categories of workers. In this sense it may not matter so much in the future, he notes, whether employment contracts are fixed-term (CDD in French) or permanent (CDI), since supposedly permanent contracts can be voided of their guarantees for employment stability and turned into contracts "at will"-a common phenomenon in the U.S. - which allow employers to exercise an escape option that they have no obligation to justify. And yet, as we have seen, precarious labor is not incompatible with a form of continuity in employment. It can even involve certain benefits, but these are informal and reversible-favors at best as opposed to rights (Alain Morice). Precarious workers are not in the strict sense "unemployable", although they are sometimes designated as such, but find themselves rather in the 
category of workers whom employers are ready to hire in spite of their status-related handicaps, as if it were indeed a favor to do so.

14 As is by now apparent, Chauvin mobilizes a wide array of references from various branches of sociology, ethnography and political economy. He draws extensively to be sure on the sociology of labor and the labor process, but also on urban sociology (including the sociology of urban marginality and the sociology of "world cities"); the sociology of race and ethnicity as it intersects with questions of class; the sociology of social movements; and, as noted earlier, the sociology of interaction in everyday life. Although Les Agences de la précarité is engaged on several theoretical fronts at once, the author is well-grounded enough in the social and human sciences to escape any suspicion of eclecticism. Throughout the frequent back-and-forth movements between analytical and narrative modes, he never loses critical focus. He has turned a portion of his doctoral dissertation, defended in 2007, into a compelling book whose insights on the contemporary forms of precarious labor, and its U.S. variants in particular, are likely to be appreciated for many years to come, even as the situation he has described evolves, since the work also provides precious tools for honing our faculties of observation.

\section{NOTES}

1. "Disqualified" in the social sense of course. All terms from the book as well as longer quotes have been translated into English for purposes of readability.

2. "Precariousness" is author Sébastien Chauvin's preferred translation for the notion of précarité. All translations into English of short passages of the book are the reviewer's.

INDEX

Thèmes : Recensions

\section{AUTEUR}

\section{JAMES COHEN}

Université Paris 3 